\title{
Potential distribution of Humid Mountain FOREST IN MEXICO
}

\author{
Gustavo Cruz-Cárdenas ${ }^{1,3}$, José Luis Villaseñor ${ }^{1}$, Lauro López-Mata² and Enrique Ortiz ${ }^{1}$ \\ 'Instituto de Biología, Departamento de Botánica, Universidad Nacional Autónoma de México, México D.F., México. \\ ${ }^{2}$ Posgrado en Botánica, Colegio de Postgraduados, Campus Montecillo, Texcoco, México. \\ ${ }^{3}$ Autor para la correspondencia: gcruzc@colpos.mx
}

\begin{abstract}
Humid Mountain Forest is one of the most important Mexican biomes due to the high floristic richness and endemism found within its small geographical extension. The distribution of this biome is not well known in the country; accordingly, the goal of this paper is to delimit its distribution by using potential distribution models of species characteristic to the biome as surrogates. Based on herbarium specimens housed at the National Herbarium of Mexico, a database of 78 species restricted or mostly restricted to Humid Mountain Forest was constructed. In addition, 56 environmental covariates (26 climatic, nine soil properties, nine topographic attributes, and 14 remote sensing data) were assembled. Species modeling was done using MaxEnt. Twenty-three covariates defined the Humid Mountain Forest distribution in Mexico. Among these, normalized vegetation index for May, total annual precipitation, and organic carbon content in the soil were the most important. According to the models, Humid Mountain Forest in Mexico represents $7 \%$ of the total surface of the country and it is found in 25 of the 32 states. Chiapas, Guerrero, Michoacán, and Oaxaca are the most outstanding states since they collectively account for $74 \%$ of the total Humid Mountain Forest surface.
\end{abstract}

Keywords: maximum entropy, MODIS remote sensing data, soil properties.

Resumen: El Bosque Húmedo de Montaña es uno de los biomas más importantes de México, pues allí se encuentra una gran riqueza florística y de endemismos, restringida a una pequeña extensión geográfica. Hasta la fecha no se sabe a ciencia cierta la extensión real de este bioma en el país; por tal razón, el objetivo de este trabajo es delimitar su distribución utilizando como variables substitutas la distribución potencial de especies vegetales características de este bioma. Con base en el estudio de especímenes de herbario depositados en el Herbario Nacional de México, se generó una base de datos de 78 especies restringidas o casi restringidas al Bosque Húmedo de Montaña. Por otra parte, se usaron 56 covariables ambientales (26 de clima, nueve propiedades de suelos, nueve atributos topográficos y 14 datos de sensores remotos). Los modelos de distribución potencial fueron elaborados utilizando el programa Maxent. Las covariables que resultaron ser significativas para la modelación de la distribución del Bosque Húmedo de Montaña fueron 23; entre las más importantes se encuentran el índice de vegetación normalizada del mes de mayo, la precipitación total anual y el contenido de carbono orgánico en el suelo. De acuerdo con el modelo, el Bosque Húmedo de Montaña en México representa $7 \%$ de su territorio y se encuentra en 25 de sus 32 entidades políticas; Chiapas, Guerrero, Michoacán y Oaxaca son los estados más importantes, pues en su territorio se ubica 74\% de la superficie total del Bosque Húmedo de Montaña.

Palabras Clave: datos de sensores remotos de MODIS, máxima entropía, propiedades de suelos.

$\mathbf{H}$ umid Mountain Forest (HMF) is found in areas with high concentrations of moisture, especially between 1,000 and 3,000 m elevation. Moisture results from the existence of rainfall during most of the year, often also due to the condensation of clouds or their persistence as fog at ground level (Villaseñor, 2010). Mountain tropical components mixed with other typically boreal plants and an abundance of climbing and epiphyte plants predominate in HMF.

HMF is among the most important Mexican biomes because it contains the richest floristic diversity per sur- face area (Rzedowski, 1978; Villaseñor, 2010). This high richness, found mostly in a relatively small surface in the mountain chains, is accompanied by high environmental heterogeneity (climate, soil, elevation) and a high degree of fragmentation throughout its distributional extent (VázquezGarcía, 1995; Ramírez-Marcial et al., 2001).

HMF (in Mexico mostly known as "bosque mesófilo de montaña", "bosque de neblina", or "mountain cloud forest") occurs in all the Mexican mountain chains, from southern Sonora and Tamaulipas to Chiapas (Challenger, 
1998; Villaseñor, 2010). This biome includes a broad set of diverse plant associations that differ in structure and composition, as well as in degree of human disturbance, and/or degree of conservation (Rzedowski, 1996; Challenger, 1998; Ramírez-Marcial et al., 2001; Luna-Vega et al., 2006).

Recently, a revision of the floristic and taxonomic literature of the Mexican HMF (Villaseñor, 2010), indicated the occurrence of 6,790 species, about $40 \%$ of which are restricted or almost restricted to the biome. The importance of HMF to the Mexican vascular flora, in addition to the high species richness, is its high level of endemic to Mexico species (34.8\%). Moreover, this biome is found in only $0.6 \%$ (Rzedowski, 1996) of the total surface of the country $\left(11,719 \mathrm{~km}^{2}\right)$, ranking its territory as that with the highest density of species per surface area, with few conservation strategies and high human population pressure. These latter conditions cast doubts on the viability of strategies proposed for the management and conservation of its natural capital, regardless of scale (national, regional, or local) (Bubb, 1991; Ramírez-Marcial et al., 2001; Ramírez-Marcial, 2002). It is estimated that more than $50 \%$ of the original surface of HMF has been replaced with grasslands for cattle grazing, farming, or for coffee plantations (Cayuela $e t$ al., 2006a). These changes in land use have caused a reduction in the structural diversity of HMF, as well as a decrease in the water quality due to the increase of contaminants in streams (Martínez et al., 2009). More than half of the present HMF surface in Mexico is classified as a high priority zone (Toledo-Aceves et al., 2011), that is, characterized by a high forest quality but endangered by human activities.

Floristic knowledge of the Mexican HMF is poor and the efforts to overcome such deficiency scarce. Therefore, information in digital format about this biome is practically absent, especially information relevant for understanding geographical patterns either of the biome in general or their species. Geographical data matched with taxonomic identities are fundamental to modeling and predicting potential species distributions (Phillips et al., 2006). Accordingly, the aim of this study was to determine the potential distribution of HMF. To do this, we determined the environmental requirements of several species restricted to this biome and then extrapolated this data as a surrogate measurement for outlining its geographic extension.

\section{Materials and methods}

Environmental covariates. 56 covariates were used, each with a $1 \mathrm{~km}^{2}$ pixel resolution; 26 included climatic covariates, nine included topographic attributes, nine included soil properties, and 14 included remote sensing data (Table 1).

Records. Localities for 78 species were obtained from specimens housed at the National Herbarium of Mexico (MEXU) of the Instituto de Biología, Universidad Nacional Autóno-
Table 1. List of covariates used to model the Humid Mountain Forest (HMF) potential distribution

\begin{tabular}{ll}
\hline Type & Covariates \\
\hline Climate & bio1 (annual mean temperature), bio2 (mean \\
diurnal range (mean of monthly (max temp - min \\
temp)), bio3 (isothermality (bio2/bio7) * (100), \\
bio4 (temperature seasonality (standard deviation \\
*100)), bio5 (maximum temperature of warmest \\
month), bio6 (minimum temperature of coldest \\
month), bio7 (temperature annual range (bio5- \\
bio6)), bio8 (mean temperature of wettest quarter), \\
bio9 (mean temperature of driest quarter), bio10 \\
(mean temperature of warmest quarter), bio11 \\
(mean temperature of coldest quarter), bio12 \\
(annual precipitation), bio13 (precipitation of \\
wettest month), bio14 (precipitation of driest \\
month), bio15 (precipitation seasonality \\
(coefficient of variation)), bio16 (precipitation of \\
wettest quarter), bio17 (precipitation of driest \\
quarter), bio18 (precipitation of warmest quarter), \\
bio19 (precipitation of coldest quarter). \\
In addition we calculated the precipitation and \\
the temperature of both the humid and dry \\
months, as well as the real annual evapotranspi- \\
ration, of the humid and dry months ${ }^{\dagger}$
\end{tabular}

Soil properties Organic matter, sodium absorption ratio, $\mathrm{pH}$, (geostatistical electric conductivity, organic carbon, potassium, analysis by sodium, magnesium, and calcium

Cruz-Cárdenas

et al. (2012)

Remote sensig 14 vegetation indices (monthly average, humid data and dry months average) from year 2009

(MODIS web)

${ }^{\dagger}$ The humid months go from May to October and the dry months from November to April; evapotranspiration was calculated based on Turc's model $(1954)$, where ETRA $=\mathrm{P} /\left[0.9+(\mathrm{P} / \mathrm{L})^{2}\right]^{1 / 2} ; \mathrm{P}=$ total annual precipitation $(\mathrm{mm}) ; \mathrm{L}=300+25 \mathrm{~T}+0.05 \mathrm{~T}^{3}$; and $\mathrm{T}=$ mean annual temperature $\left({ }^{\circ} \mathrm{C}\right)$.

ma de México (Table 2). All records fulfilled the following two requirements: (1) their taxonomic identification was correct (annotated by a taxonomist specialist) and (2) they belong to species known to be restricted or almost restricted to HMF (Villaseñor, 2010), occurring only in one or more of the vegetation types included by Villaseñor (2010) as constituting HMF.

To validate HMF distribution model, a set of herbarium records of the family Asteraceae that indicated specifically as collecting stations HMF were used ( $\mathrm{N}=4,400$ records), as well as the distribution records of Liquidambar styraciflua L. a flagship species used to recognize this biome in the field. Both sets of records were used once HMF map was obtained, to compare how well the data fit such a map. 
Table 2. List of species and number of records used as presence data.

\begin{tabular}{|c|c|c|}
\hline Family & Species & Records \\
\hline Verbenaceae & Aegiphila valerioi Standl. & 1 \\
\hline Asteraceae & Ageratina pendula Panero \& Villaseñor & 1 \\
\hline Santalaceae & Antidaphne viscoidea Poepp. \& Endl. & 2 \\
\hline Rubiaceae & $\begin{array}{l}\text { Arachnothryx guerrerensis (Lorence) } \\
\text { Borhidi }\end{array}$ & 1 \\
\hline Rubiaceae & Arachnothryx tacanensis (Lundell) Borhidi & 3 \\
\hline Asteraceae & Archibaccharis blakeana Standl. \& Steyerm. & 1 \\
\hline Begoniaceae & Begonia purpusii Houghton ex Ziesenh. & 2 \\
\hline Papaveraceae & Bocconia vulcanica Donn. Sm. & 1 \\
\hline Orchidaceae & $\begin{array}{l}\text { Camaridium soconuscana (Breedlove } \\
\text { \& D.Mally) M.A.Blanco }\end{array}$ & 1 \\
\hline Orobanchaceae & Castilleja chiapensis Brandegee & 1 \\
\hline Orobanchaceae & Castilleja hirsuta M.Martens \& Galeotti & 1 \\
\hline Asteraceae & Critonia paneroi B.L.Turner & 2 \\
\hline Asteraceae & Critoniopsis shannonii (J.M.Coult.) H.Rob. & 1 \\
\hline Cyrillaceae & Cyrilla racemiflora L. & 11 \\
\hline Thymelaeaceae & Daphnopsis mexiae Nevling & 1 \\
\hline Asparagaceae & $\begin{array}{l}\text { Furcraea martinezii García-Mend. } \\
\text { \& L.de la Rosa }\end{array}$ & 2 \\
\hline Schlegeliaceae & $\begin{array}{l}\text { Gibsoniothamnus cornutus (Donn.Sm.) } \\
\text { A.H.Gentry }\end{array}$ & 2 \\
\hline Rubiaceae & $\begin{array}{l}\text { Gonzalagunia chiapasensis (Standl.) } \\
\text { Standl. \& Steyerm. }\end{array}$ & 5 \\
\hline Orchidaceae & $\begin{array}{l}\text { Goodyera brachyceras (A.Rich. \& Galeotti) } \\
\text { Garay \& G.A.Romero }\end{array}$ & 6 \\
\hline Olacaceae & Heisteria macrophylla Oerst. & 1 \\
\hline Rubiaceae & Hoffmannia cauliflora Hemsl. & 2 \\
\hline Rubiaceae & Hoffmannia guerrerensis Borhidi \& J.Rojas & 1 \\
\hline Rubiaceae & Hoffmannia macrosiphon Standl. & 1 \\
\hline Amaryllidaceae & Hymenocallis guerreroensis T.M.Howard & 2 \\
\hline Lamiaceae & Hyptis glomerata Benth. & 1 \\
\hline Acanthaceae & Justicia santelisiana Acosta \& T.F.Daniel & 1 \\
\hline Brassicaceae & $\begin{array}{l}\text { Lepidium virginicum L. var. } \\
\text { centrali-americanum (Thell.) C.L.Hitchc. }\end{array}$ & 1 \\
\hline Lauraceae & Licaria chinanteca Lorea-Hern. & 4 \\
\hline Solanaceae & Lycianthes connata J.L.Gentry & 7 \\
\hline Melastomataceae & Meriania macrophylla (Benth.) Triana & 1 \\
\hline Fabaceae & $\begin{array}{l}\text { Mimosa albida Humb. \& Bonpl. ex } \\
\text { Willd. var. pochutlensis R.Grether }\end{array}$ & 5 \\
\hline Monimiaceae & Mollinedia orizabae Perkins & 1 \\
\hline Gesneriaceae & $\begin{array}{l}\text { Moussonia hirsutissima (C.V.Morton) } \\
\text { Wiehler }\end{array}$ & 2 \\
\hline Gesneriaceae & $\begin{array}{l}\text { Moussonia skutchii (C.V.Morton \& } \\
\text { D.N.Gibson) Wiehler }\end{array}$ & 2 \\
\hline Orchidaceae & Myoxanthus octomeriae (Schltr.) Luer & 1 \\
\hline Asteraceae & Neurolaena oaxacana B.L.Turner & 4 \\
\hline Lauraceae & Ocotea sauroderma Lorea-Hern. & 6 \\
\hline Orchidaceae & Oncidium laeve (Lindl.) Beer & 8 \\
\hline
\end{tabular}

Potential distribution modeling. Modeling of HMF potential distribution was done using two sets of covariates. The first used only the 19 WorldClim covariates, and the second selected the covariates based on the following procedure (Yost et al., 2008): (1) MaxEnt (Phillips et al., 2006) was run using the 56 covariates, (2) the gain values were extracted from the Jackknife validation test and a mean test

\begin{tabular}{|c|c|c|}
\hline Family & Species & Records \\
\hline Orchidaceae & $\begin{array}{l}\text { Oncidium wentworhtianum Bateman } \\
\text { ex Lindl. }\end{array}$ & 1 \\
\hline Rubiaceae & Palicourea heydei (Standl.) Lorence & 1 \\
\hline Santalaceae & Phoradendron heydeanum Trel. & 5 \\
\hline Phyllanthaceae & Phyllanthus barbarae M.C.Johnst. & 2 \\
\hline Lentibulariaceae & $\begin{array}{l}\text { Pinguicula hemiepiphytica Zamudio } \\
\text { \& Rzed. }\end{array}$ & 1 \\
\hline Lentibulariaceae & Pinguicula laueana Speta \& F.Fuchs & 1 \\
\hline Lentibulariaceae & Pinguicula laxifolia Luhrs & 1 \\
\hline Lentibulariaceae & Pinguicula zecheri Speta \& Fuchs & 3 \\
\hline Piperaceae & Piper tacticanum Trel. \& Standl. & 3 \\
\hline Asteraceae & $\begin{array}{l}\text { Podachaenium chiapanum B.L.Turner } \\
\text { \& Panero }\end{array}$ & 3 \\
\hline Orchidaceae & Prosthechea neurosa (Ames) W.E.Higgins & 3 \\
\hline Asteraceae & Roldana gilgii (Greenm.) H.Rob. \& Brettell & 2 \\
\hline Asteraceae & Roldana greenmanii H.Rob. \& Brettell & 1 \\
\hline Orchidaceae & $\begin{array}{l}\text { Rossioglossum grande (Lindl.) Garay } \\
\text { \& G.C.Kenn. }\end{array}$ & 4 \\
\hline Rosaceae & Rubus philyrophyllus Rydb. & 4 \\
\hline Acanthaceae & Ruellia conzattii Standl. & 2 \\
\hline Asteraceae & Rumfordia revealii H.Rob. & 3 \\
\hline Rubiaceae & Sabicea mexicana Wernham & 9 \\
\hline Lamiaceae & Salvia wagneriana Pol. & 7 \\
\hline Schisandraceae & Schisandra glabra (Brickell) Rehder & 5 \\
\hline Crassulaceae & Sedum grandipetalum Fröd. & 1 \\
\hline Crassulaceae & Sedum multiflorum R.T.Clausen & 3 \\
\hline Sapindaceae & Serjania insignis Radlk. & 1 \\
\hline Gesneriaceae & Solenophora chiapasensis D.N.Gibson & 1 \\
\hline Rubiaceae & Sommera chiapensis Brandegee & 2 \\
\hline Asteraceae & $\begin{array}{l}\text { Squamopappus skuktchii (S.F.Blake) } \\
\text { R.K.Jansen, N.A. Harriman \& Urbatsch }\end{array}$ & 2 \\
\hline Melastomataceae & $\begin{array}{l}\text { Stanmarkia medialis (Standl. \& Steyerm.) } \\
\text { Almeda }\end{array}$ & 2 \\
\hline Orchidaceae & Stelis oaxacana R.Solano & 3 \\
\hline Orchidaceae & Stelis tacanensis R.Solano \& Soto Arenas & 1 \\
\hline Acanthaceae & Stenostephanus guerrerensis T.F.Daniel & 1 \\
\hline Pentaphylacaceae & Symplococarpon flavifolium Lundell & 2 \\
\hline Symplocaceae & Symplocos jurgensenii Hemsl. & 2 \\
\hline Asteraceae & Tagetes nelsonii Greenm. & 3 \\
\hline Asteraceae & Tetrachyron torresii B.L.Turner & 1 \\
\hline Thelypteridaceae & $\begin{array}{l}\text { Thelypteris glandulosa (Desv.) Proctor } \\
\text { var. brachyodus (Kunze) A.R.Sm. }\end{array}$ & 1 \\
\hline Hypericaceae & $\begin{array}{l}\text { Thornea matudae (Lundell) Breedlove } \\
\text { \& E.M.McClint. }\end{array}$ & 3 \\
\hline Bromeliaceae & Tillandsia velutina Ehlers & 1 \\
\hline Orchidaceae & Trichosalpinx memor (Rchb. f.) Luer & 1 \\
\hline Asteraceae & Vernonia solorzanoana Rzed. \& Calderón & 1 \\
\hline Asteraceae & Vernonia wendtiana B.L.Turner & 1 \\
\hline
\end{tabular}

(95\% significance level) was applied to determine their confidence intervals, (3) the covariates with values higher than the upper maximum of the confidence interval were selected, and (4) a second MaxEnt analysis was run only using the selected covariates (in step 3).

Each run in Maxent used the records of the 78 species selected as characteristic of HMF. The records were divided 
in two sets, the first (75\% of data), was used for training and the second one $(25 \%)$ for modeling validation. Regularization and trait kind were obtained using the automatic option with 10,000 background points; the convergence threshold was $10^{-5}$, the maximum number of iterations was 500 , and the output exit was the logistic one; in all cases we followed the performance proposal of Phillips and Dudik (2008).

The potential distribution coverage in logistic format obtained from each modeling case was the transformed Boolean-layer. This layer was used to determine HMF potential distribution. To do this, the $10 \%$ omission error criterion (pixels equal or larger than this value were re-classified as 1 and the others as 0) was used, in this way a high proportion of presences was estimated adequately, with the lowest presence's threshold maintained (Pearson et al., 2007). The potential distribution of Liquidambar styraciflua was obtained with the same procedure.

Statistical analyses. We evaluated accuracy among maps with a proportions test. The number of successes was obtained by quantifying the validation records with predic-
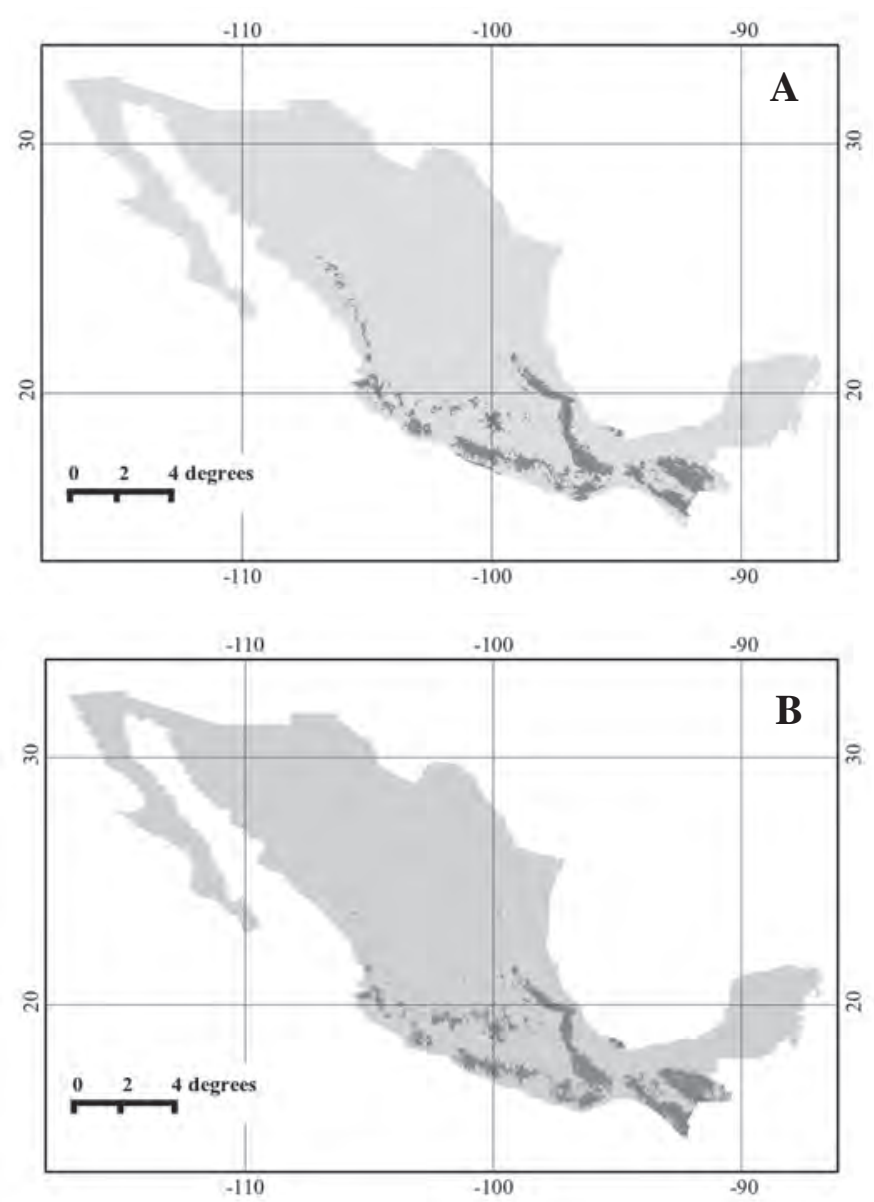

Figure 1. HMF potential distribution models obtained with two methods: A) using the 19 WorldClim covariates, B) using the gain values of the jackknife test based on 23 covariates.
Table 3. Covariates recorded as important in HMF potential distribution modeling according to two different methods.

\begin{tabular}{|c|c|c|c|}
\hline Covariates & $\begin{array}{c}\text { Group } 1 \\
\text { (WorldClim) }\end{array}$ & $\begin{array}{l}\text { Group } 2 \\
\text { (Jackknife) }\end{array}$ & Frequency \\
\hline NDVlapril2009 & & 1 & 1 \\
\hline NDVlaugust2009 & & 1 & 1 \\
\hline bio1 & 1 & & 1 \\
\hline bio2 & 1 & 1 & 2 \\
\hline bio3 & 1 & & 2 \\
\hline bio4 & 1 & 1 & 2 \\
\hline bio5 & 1 & 1 & 2 \\
\hline bio6 & 1 & & 1 \\
\hline bio7 & 1 & 1 & 2 \\
\hline bio8 & 1 & & 1 \\
\hline bio9 & 1 & & 1 \\
\hline bio10 & 1 & & 1 \\
\hline bio11 & 1 & & 1 \\
\hline bio12 & 1 & 1 & 2 \\
\hline bio13 & 1 & 1 & 2 \\
\hline bio14 & 1 & & 1 \\
\hline bio15 & 1 & & 1 \\
\hline bio16 & 1 & 1 & 2 \\
\hline bio17 & 1 & & 1 \\
\hline bio18 & 1 & & 1 \\
\hline bio19 & 1 & & 1 \\
\hline OC & & 1 & 1 \\
\hline NDVIdecember2009 & & 1 & 1 \\
\hline NDVIjanuary2009 & & 1 & 1 \\
\hline NDVIfebruary2009 & & 1 & 1 \\
\hline NDVIH2009 & & 1 & 1 \\
\hline NDVIjuly2009 & & 1 & 1 \\
\hline NDVIjune2009 & & 1 & 1 \\
\hline NDVImarch2009 & & 1 & 1 \\
\hline NDVImay2009 & & 1 & 1 \\
\hline OM & & 1 & 1 \\
\hline NDVInovember2009 & & 1 & 1 \\
\hline NDVloctober2009 & & 1 & 1 \\
\hline $\mathrm{PPH}$ & & 1 & 1 \\
\hline NDVIS2009 & & 1 & 1 \\
\hline
\end{tabular}

Covariates with bio acronym see Table 1 ; $\mathrm{OC}=$ organic carbon; NDVIH2009 = normalized difference vegetation index of the humid months of 2009; OM = organic matter; $\mathrm{PPH}=$ precipitation of the humid months; NDVI2009 = normalized difference vegetation index of the dry months of 2009.

tion probability values higher than the previously defined threshold (Baldwin and Bender, 2008). In the same way, the proportions test was used to evaluate the accuracy between HMF map and the placement of the Asteraceae records on it. From the two maps obtained (19 covariates only and 24 covariates with Jackknife selection), that with better accuracy to extract covariate values corresponding to each pixel covering HMF surface was used. The covariate values were then used to determine confidence intervals for each co- 
variate with the percentiles method (Efron, 1981). A 95\% significance level criterion was used and the intervals with 2.5 (left side) and 97.5 (right side) percentile values of each covariate were likewise calculated.

Software. The geographical analysis was done using Quantum GIS 1.7.0 and the statistical analysis using R (R Development Core Team, 2011).

\section{Results}

HMF contains 2,872 species restricted or almost restricted to its territory (Villaseñor, 2010); unfortunately a large number of them have neither enough different collecting stations nor precise localities to be used in modeling strategies (geographical coordinates). In total, 78 species were selected under conventional criteria used to determine HMF occurrence (Table 2); this number was considered enough (as results indicate), especially for the number of different records evaluated $(\mathrm{N}=190)$. Hernandez et al. (2006) considered 50 records represent a reasonable size to carry out modeling exercises; however, the study area size needs to be considered. Cruz-Cárdenas et al. (2010) suggest that sample size correspond to $15-20 \%$ of pixels covering the study area if satisfactory modeling results are expected. Therefore, considering that the scale of Rzedowski's potential vegetation map (Rzedowski, 1996) is 1:4000 000, the pixel's size is $4 \times 4 \mathrm{~km}$ (Bishop et al., 2001); if we divide the surface of HMF estimated in such a map $\left(11,719 \mathrm{~km}^{2}\right)$, we find that
733 pixeles occupy the surface of this biome. Finally, if each record represents a pixel, our sample size should be between 111 and 145 records; our sample size exceeds this range (190 records); therefore, according to this criterion enough records were used in HMF modeling.

The number of covariates varies according to the method used for HMF modeling (Table 1). For example, group 1 (WorldClim) includes all 19 covariates as important, whereas group 2 (Jackknife) records 23 covariates as important, not all of them strictly climatic ones. Only annual precipitation (bio12) and the precipitation of the wettest quarter (bio16) were recovered as important by both methods.

The estimated surface of HMF based on the two modeling methods is quite similar; on average it measures 139,405 $\mathrm{km}^{2}$, which represents about $7 \%$ of the Mexican territory. Each model records slight differences, especially in those areas where HMF has not been previously recorded. However, there were no significant differences among accuracy of the maps generated with the covariates used by each of the two methods (Table 4). Based on these results, the po-

Table 4. HMF distribution maps accuracy (successes/trials) $\times 100)$ modeled with two covariate sets.

\begin{tabular}{lccc}
\hline Model & Successes & Trials & \% Accuracy \\
\hline Jackknife & 25 & 29 & $89.6 \mathrm{~ns}$ \\
WorldClim & 26 & 29 & $86.2 \mathrm{~ns}$ \\
\hline
\end{tabular}

ns= The proportion test indicates no-significant differences.

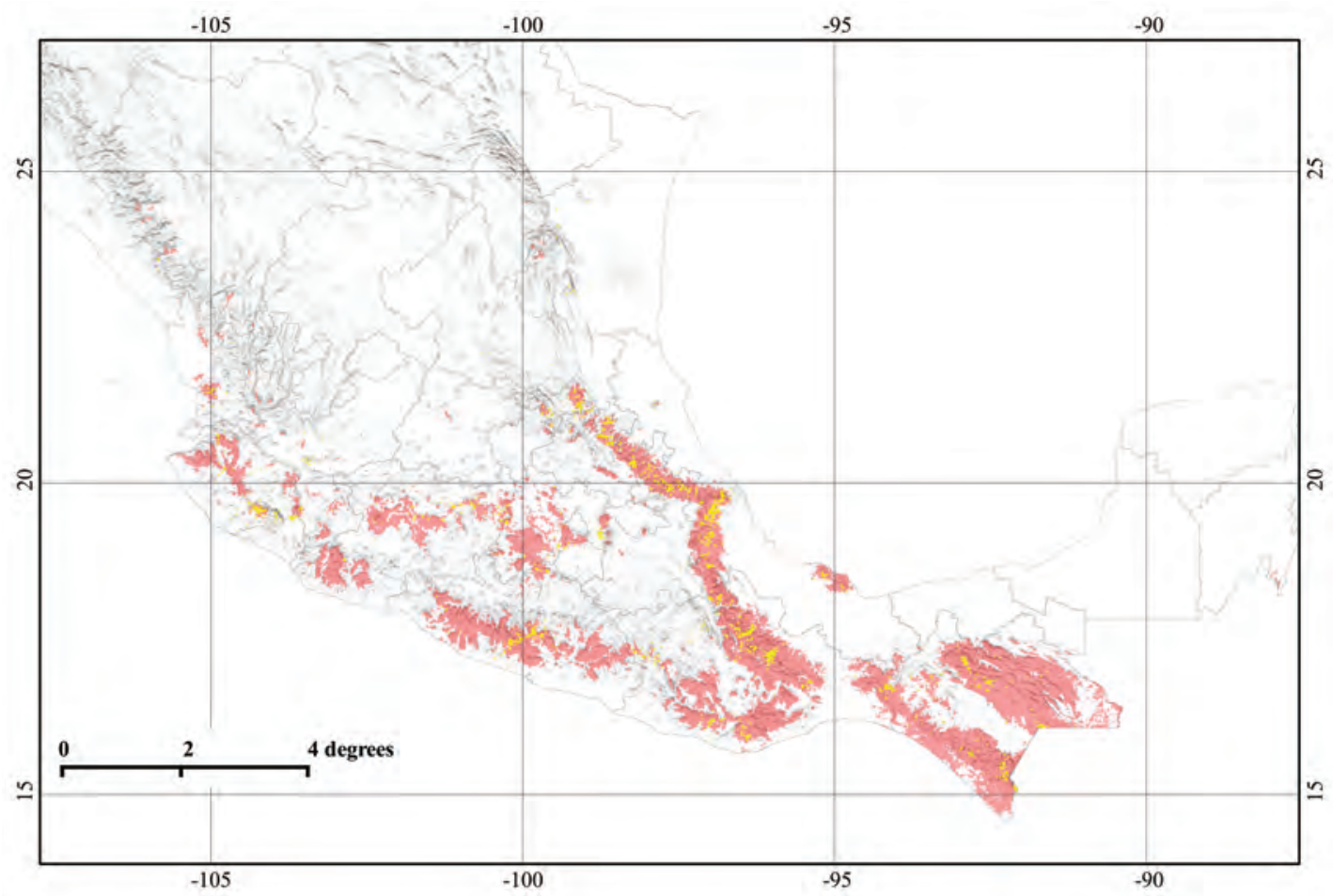

Figure 2. HMF potential distribution in Mexico and the field localities of Asteraceae species recorded for this biome (yellow points). 

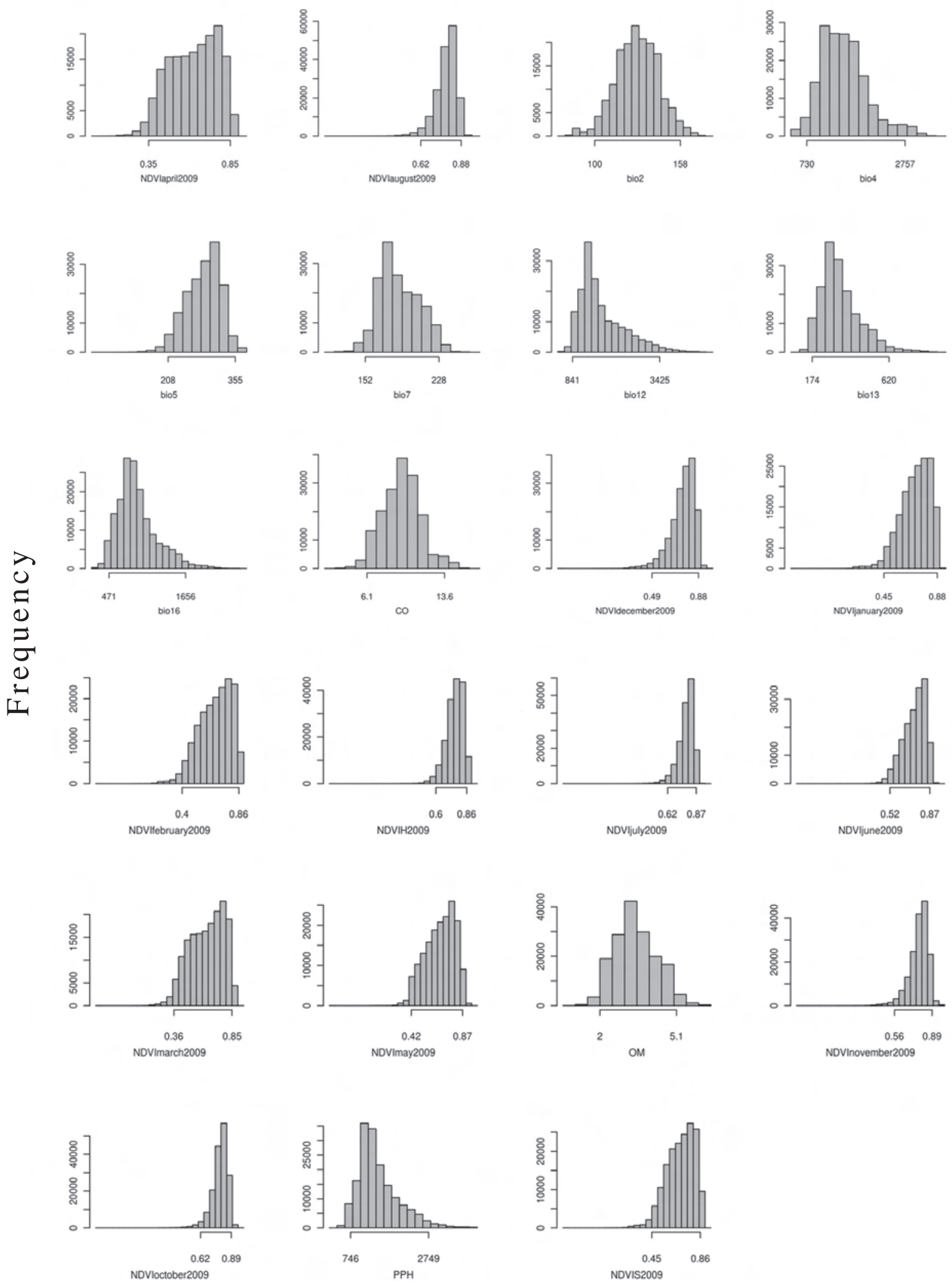

Figure 3. Histograms and confidence intervals ( $95 \%$ significance level) of covariates that better explain HMF distribution in Mexico. Covariates with acronym bio see Table 1; OC = organic carbon; NDVIH2009 = normalized difference vegetation index of the humid months of 2009; OM = organic matter; PPH = precipitation of the humid months; NDVIS2009 = normalized difference vegetation index of the dry months of 2009. 
Table 5. Asteraceae collecting records citing the occurrence of HMF but not coincident with the polygon of its potential distribution $(\mathrm{N}=$ 4,440; non-coincident $=845$ ).

\begin{tabular}{lc}
\hline State & Records \\
\hline Estado de México & 124 \\
Michoacán & 117 \\
Oaxaca & 113 \\
Jalisco & 110 \\
Querétaro & 53 \\
Colima & 52 \\
Tamaulipas & 46 \\
Chiapas & 45 \\
Hidalgo & 41 \\
Veracruz - Llave & 41 \\
Guerrero & 35 \\
Nayarit & 22 \\
Nuevo León & 12 \\
San Luis Potosí & 11 \\
Sinaloa & 11 \\
Morelos & 6 \\
Puebla & 5 \\
Durango & 4 \\
\hline
\end{tabular}

tential distribution of HMF is given only with the polygon generated by the Jackknife method (group 2, Figure 1b).

Figure 2 shows that HMF may occur in 25 out of 32 Mexican states. The larger HMF geographical extension was found in four states: Chiapas (30\%), Oaxaca (23\%), Guerrero (12\%), and Michoacán (9\%). Additional potential surface (24\%) was located in the states of Hidalgo, Jalisco, México, Nayarit, Puebla, and Veracruz and only $2 \%$ of HMF potential surface is found in the states of Colima, Distrito Federal, Durango, Guanajuato, Morelos, Nuevo León, Querétaro, San Luis Potosí, Sinaloa, Tabasco, Tamaulipas, Tlaxcala, and Zacatecas. Neither literature nor herbarium vouchers had recorded the occurrence of HMF in Guanajuato, Tabasco, Tlaxcala, or Zacatecas.

The validation test using the Asteraceae records $(\mathrm{N}=$ 4,440 ) indicates that 3,952 of them match the modeled surface (Figure 2). This result indicates a confidence interval of map precision between $80 \%$ and $82 \%$ (95\% significance level). The states of Colima, Jalisco, México, Michoacán, Oaxaca, and Querétaro included 66\% of the records misplaced outside HMF contour (Table 5).

Figure 3 shows the histograms with the confidence intervals of the covariates disclosed as important in HMF modeling. From them, 13 were of remote sensing data, eight were climatic, and two were soil properties. The covariates with less than $50 \%$ variation among their confidence intervals were the normalized vegetation indices for July (40\%), March (42\%), August (42\%), October (44\%), and the set of humid months (43\%). Covariates with more than $100 \%$ variation among their confidence intervals were the normal- ized vegetation indices for May (107\%), February (115\%), and April (143\%), the OC (123\%), the OM (155\%), the precipitation of the wettest quarter (bio16, 252\%), the precipitation of the wettest months (bio13, 256\%), the precipitation of the humid months (268\%), the temperature seasonality (bio4, 278\%), and the annual precipitation (bio12, 307\%).

\section{Discussion}

Rzedowski (1996) mentions a number of families as important members of HMF flora, among them Asteraceae, Orchidaceae, Polypodiaceae, and Rubiaceae. Several species here used to model HMF potential geographical distribution are members of these families, as well as many others that jointly integrate its natural capital (Table 2). Species distribution along the taxonomic hierarchy allows us to assume that an important component of the generic potential that has contributed to this floristic richness is included. Therefore, results can confidently represent places where HMF can be considered as a natural laboratory where much of the biological diversification of this biome has taken place.

Results suggest that HMF potential surface constitutes $7 \%$ of Mexico's territory. This is a value six times larger than those reported by Rzedowski (1996) or Ortega-Escalona and Castillo-Campos (1996). A comparison of Figure 4 with Rzedowski's map (1996) indicates they are congruent in $81 \%$ of the surface; however, it is important to point out that Rzedowski's HMF polygon only includes $10 \%$ of the total surface obtained in this work for HMF.

Liquidambar styraciflua is commonly considered a species characteristic of HMF; that is, where this species occurs most surely HMF is or was present. However, if its potential distribution is compared with the potential distribution of all HMF, we see that only $66 \%$ of its distribution matches HMF polygon. This result suggests a $66 \%$ success rate for predicting HMF if we look at Liquidambar's distribution. Caution has then to be taken in the selection of a species as flagship or indicator of a particular biome.

As mentioned above, Chihuahua, Guanajuato, Quintana Roo, Tabasco, Tlaxcala, and Zacatecas are Mexican states without prior reference to the occurrence of HMF in their territory. Surely the boundary effect plays an important role in HMF identification in those states. For example, this study indicates that there are potential sites where HMF can be present in Tabasco and Tlaxcala, occupying according to the model 169 and $123 \mathrm{~km}^{2}$ respectively. Recently, López et al. (2011) reported the occurrence of small patches of HMF in the Municipality of Huimanguillo (Tabasco); this finding supports the effectiveness of ecological modeling in the identification of places with a particular kind of biome. Future fieldwork in Guanajuato, Tlaxcala or Zacatecas may confirm the occurrence of HMF in its territory, as our results suggest; our experience indicates that canyons with a north aspect should be searched for its potential existence. 


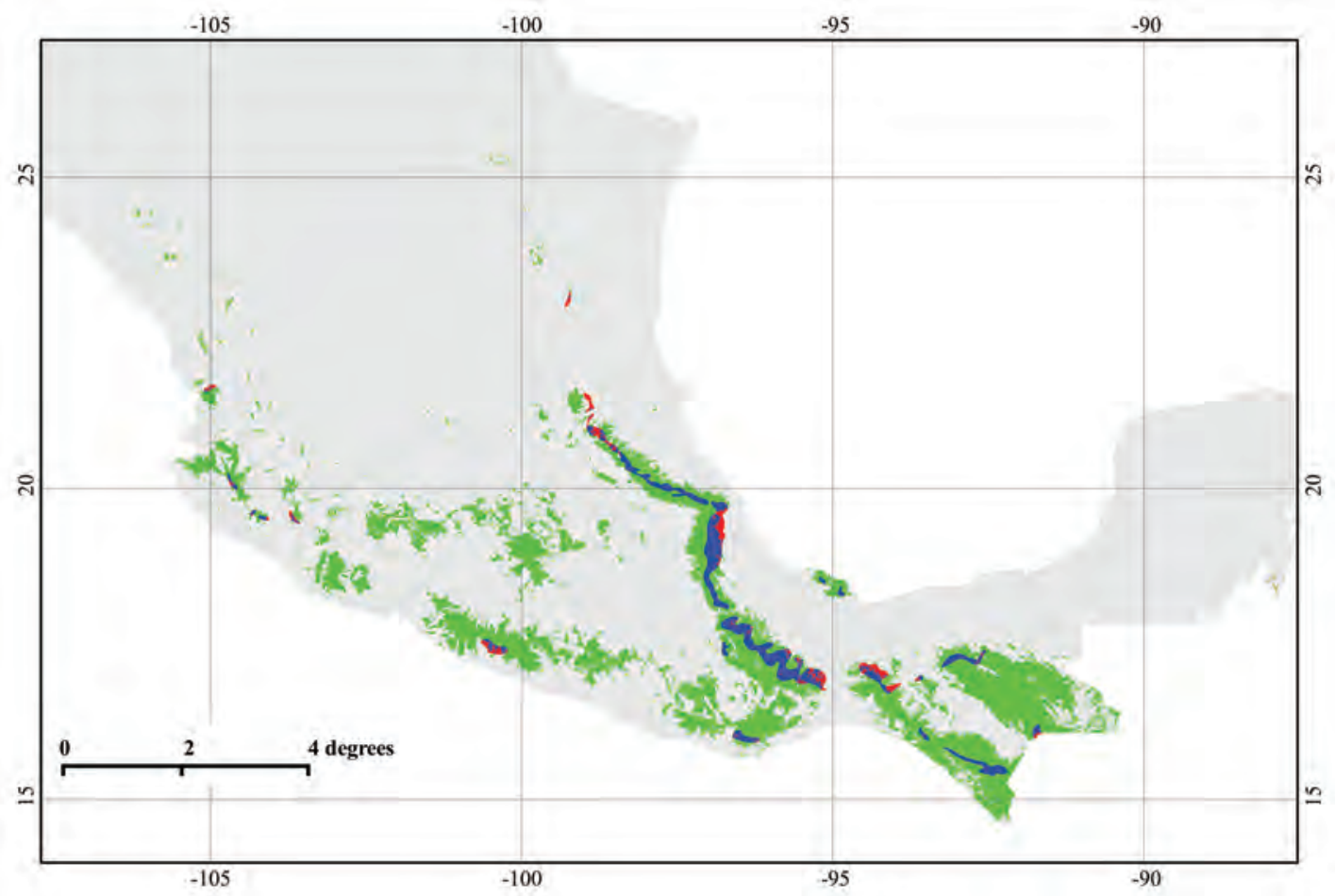

Figure 4. Comparison of HMF potential distribution polygon obtained in this study and Rzedowski (1978). Red color HMF sensu Rzedowski; green color HMF sensu this work; blue color shared areas.

The accuracy error (19\%) in HMF contour when compared with the Asteraceae records can be explained in several ways. Perhaps some records used in this study may be wrongly assigned to the biome, that is, they do not belong to HMF ("confusion level"); this could be the case of 59 records from the State of México (Tlalmanalco and Amecameca localities), 13 from Jalisco (Jocotepec and Tlajomulco), 33 from Michoacán (Ocampo and Zitácuaro), or 11 from Nuevo León (Santiago). When we omitted these 116 Asteraceae records, supposedly incorrectly assigned to this biome, accuracy error diminishes to $16 \%$, a figure closer to the accuracy values obtained with the models (Table 4).

The vegetation indices for March, April, and May are the remote sensing covariates with the highest gain values. These months in México correspond to the wet half of the dry season, when important phenological patterns are observed, for example the high chlorophyll production favored by the higher carbon capture due to higher solar radiation (Xiao et al., 2006). Moreover, the use of remote sensing data has showed their usefulness to discriminate across vegetation types; for example, Cayuela et al. (2006b) obtained a map where six vegetation classes were identified (HMF included) with more than $70 \%$ accuracy.

Among the climatic covariates, precipitation was the most important for determining HMF occurrence. Our results agree with previous studies, where humidity was also a characteristic factor for explaining HMF occurrence; hu- midity can be observed as precipitation or mist. Mist can contribute to HMF humidity with $1 \mathrm{~mm}$ per day during the dry season, and up to $0.5 \mathrm{~mm}$ per day during the rainy season (Holder, 2004). Ortega-Escalona and Castillo-Campos (1996) mention that HMF occurs in areas where total annual precipitation is higher than $1,000 \mathrm{~mm}$ but less than 2,300 $\mathrm{mm}$; however, some places with HMF exceed 3,000 mm precipitation, for example in the Chinantla region of Oaxaca (Meave et al., 1992).

The organic carbon content is the most important soil property and soil variation may be explained by the age of the forest. Bautista-Cruz et al. (2004) discuss that HMF sites that are 100 years old or more have soils with higher organic carbon content. On the other hand, soils with neutral $\mathrm{pH}$ (6.5-7.0) and therefore with less organic carbon content are found in places where HMF average less than 100 years of age. The important correlation of this covariate with HMF potential distribution modeling would allow us to use the organic carbon content as a useful parameter to estimate potential ages of patches with HMF.

The largest extension of HMF potential distribution in México is located in the states along the Pacific Ocean slope (Chiapas, Colima, Guerrero, Jalisco, Nayarit, and Oaxaca). The Gulf of México slope concentrates the larger potential surface in the states of Hidalgo, Puebla, Querétaro, and Veracruz. Along the Gulf of México slope the potential surface for this biome is significantly smaller than along the Pacific Ocean slope. However, the former patches generally 
record higher precipitation values $(2,300 \mathrm{~mm}$ or more) than do those in the Pacific Ocean slope (1,200 to 2,300 $\mathrm{mm}$ ). Several areas in the central part of the country with real or potential patches of HMF show the lowest records of total annual precipitation.

The soil organic carbon content (OC) does not follow a pattern associated with the continental slopes. The soils with highest $\mathrm{OC}$ content $\left(>10 \mathrm{~kg} \mathrm{~m}^{-2}\right.$ ) are located in patches of HMF in the states of Chiapas, Hidalgo, Jalisco, Michoacán, Oaxaca, Querétaro, and Veracruz; in contrast, HMF in Guerrero has soils with the lowest OC content.

Ecological species modeling, as our results indicate, can provide significant information to understand the present, past, and potential distribution of vegetation types and their biotic elements. HMF potential surface obtained in this study may need field work validation, in order to verify the localities that still remain with this important biome and its endangered biota.

\section{Acknowledgments}

The first author thanks the Universidad Nacional Autónoma de México (UNAM), for a postdoctoral fellowship granted through its 2010 Postdoctoral Fellowhip Program of its Dirección General de Asuntos del Personal Académico. Part of the information used was obtained when José Luis Villaseñor and Lauro López-Mata were on sabbatical leaves, the former at the Comisión Nacional para el Conocimiento y Uso de la Biodiversidad (CONABIO) and the latter at the Departamento de Botánica del Instituto de Biología, UNAM. We thank David S. Gernandt and Claudio Delgadillo for the idiom's review.

\section{Literature cited}

Baldwin R.A. and Bender L.C. 2008. Den-Site characteristics of black bears in Rocky Mountain National Park, Colorado. The Journal of Wildlife Management 72:1717-1724.

Bautista-Cruz A., Gutiérrez-Castorena M. del. C., del CastilloSánchez F.R. y Etchevers-Barra J.D. 2004. Cronosecuencia de un suelo y su clasificación en un área originalmente ocupada por bosque mesófilo de montaña. Terra Latinoamericana 23:147-157.

Bishop T.F.A., McBratney A.B. and Whelan B.M. 2001. Measuring the quality of digital soil maps using information criteria. Geoderma 103:95-111.

Bubb P. 1991. The current situation of the cloud forest in northern Chiapas, Mexico. ECOSFERA/PRONATURA/The Percy Sladen Memorial Found, Fauna and Flora Preservation Society, Edinborough.

Cayuela L., Golicher D.J. and Rey-Benayas J.M. 2006a. The extent, distribution, and fragmentation of vanishing montane cloud forest in the highlands of Chiapas, Mexico. Biotropica 38:544-554.

Cayuela L., Golicher J.D., Salas-Rey J. and Rey-Benayas J.M. 2006b. Classification of a complex landscape using Dempster-
Shafer theory of evidence. International Journal of Remote Sensing 27:1951-1971.

Challenger A. 1998. Utilización y Conservación de los Ecosistemas Terrestres de México. Pasado, Presente y Futuro. Comisión Nacional para el Conocimiento y uso de la Biodiversidad/Universidad Nacional Autónoma de México, México, D.F.

Cruz-Cárdenas G., López-Mata L., Ortiz-Solorio C.A., Villaseñor J.L. and Ortiz E. 2012. Spatial analysis of Mexican soil properties at 1:1,000,000 scale. Geoderma (In press).

Cruz-Cárdenas G., Ortiz-Solorio C.A., Ojeda-Trejo E., MartínezMontoya J.F., Sotelo-Ruiz E.D. and Licona-Vargas A.L. 2010. Digital mapping of farmland classes in three landscapes in Mexico. Journal of Soil Science and Plant Nutrition 10:414-427.

Efron B. 1981. Nonparametric standard errors and confidence intervals. The Canadian Journal of Statistics/La Revue Canadienne de Statistique 9:139-158.

Hernandez P.A., Graham C.H., Master L.L. and Albert D.L. 2006. The effect of sample size and species characteristics on performance of different species distribution modeling methods. Ecography 29:773-785.

Holder C.D. 2004. Rainfall interception and fog precipitation in a tropical montane cloud forest of Guatemala. Forest Ecology and Management 190:373-384.

López L.D., Castillo A.O. y Zavala C.J. 2011. Estructura y composición florística del bosque mesófilo de montaña. In: Sociedad Científica Mexicana de Ecología Eds. III Congreso Mexicano de Ecología, los Retos de la Investigación Ecológica ante la Problemática Ambiental: Resumenes de Carteles, pp. 215, Sociedad Científica Mexicana de Ecología, Veracruz. <www. uv.mx/congreso-ecologia-2011/resumenes_files/CongresoEcologiaResumenesCarteles.pdf> (accessed June 2011).

Luna-Vega I., Alcantara-Ayala O., Ruíz-Jiménez C.A. and Contreras-Medina R. 2006. Composition and structure of humid montane oak forests at different sites in central and eastern Mexico. In: Kapelle M. Ed. Ecology and Conservation of Neotropical Montane Oak Forests, pp. 101-112, Springer-Verlag, New York.

Martínez M.L., Pérez-Maqueo O., Vázquez G., Castillo-Campos G., García-Franco J., Mehtreter K., Equiahua M. and Landgrave R. 2009. Effects of land use change on biodiversity and ecosystem services in tropical montane cloud forests of Mexico. Forest Ecology and Management 258:1856-1863

Meave J., Soto M., Calvo L., Paz H. y Valencia S. 1992. Análisis sinecológico del bosque mesófilo de montaña de Omitelmi, Guerrero. Boletín de la Sociedad Botánica de México 52:3177.

Ortega-Escalona F. y Castillo-Campos G. 1996. El bosque mesófilo de montaña y su importancia forestal. Ciencias 43:32-39.

Pearson R.G., Raxworthy C.J., Nakamura M. and Peterson A.T. 2007. Predicting species distribution from small numbers of occurrence records: a test case using cryptic geckos in Madagascar. Journal of Biogeography 34:102-117.

Phillips S.J. and Dudik M. 2008. Modeling of species distributions with MaxEnt: new extensions and a comprehensive evaluation. Ecography 31:161-175.

Phillips S.J., Anderson R.P. and Schapire R.E. 2006. Maximum entropy modeling of species geographic distributions. Ecological Modelling 190:231-259.

R Development Core Team. 2011. R: A language and environment for statistical computing. - R Foundation for Statistical Com- 
puting, Vienna. <www.R-project.org>

Ramírez-Marcial N. 2002. Disturbio humano y la diversidad de árboles y arbustos del Bosque Mesófilo en las montañas del norte de Chiapas. Tesis doctoral, Instituto de Ecología, A.C. Xalapa, Veracruz. México. 158 pp.

Ramírez-Marcial N., González-Espinosa M. and Williams-Linera G. 2001. Anthropogenic disturbance and tree diversity in montane rain forests in Chiapas, Mexico. Forest Ecology and Management 154:311-326.

Riley S.J., DeGloria S.D. and Elliot R. 1999. A terrain ruggedness index that quantifies topographic heterogeneity. Intermountain Journal Sciences 5:23-27.

Rzedowski J. 1978. Vegetación de México. Limusa. México, D.F.

Rzedowski J. 1996. Análisis preliminar de la flora vascular de los bosques mesófilos de montaña de México. Acta Botanica Mexicana 35:25-44.

Sappington J.M., Longshore K.M. and Thompson D.B. 2007. Quantifying landscape ruggedness for animal habitat analysis: A case study using Bighorn sheep in the Mojave Desert. Journal of Wildlife Management 71:1419-1426.

Toledo-Aceves T., Meave J.A., González-Espinosa M. and
Ramírez-Marcial N. 2011. Tropical montane cloud forests: Current threats and opportunities for their conservation and sustainable management in Mexico. Journal of Environmental Management 92:974-981.

Vázquez-García J.A. 1995. Cloud forests archipelagos: Preservation of fragmented montane ecosystems in tropical America. In: Hamilton L.S., Juvik O.J. and Scatena F.N. Eds. Tropical Montane Cloud Forests, pp. 315-332, East-West Center, Program on Environment, Honolulu.

Villaseñor J.L. 2010. El Bosque Húmedo de Montaña en México y sus Plantas Vasculares: Catálogo Florístico-Taxonómico. Comisión Nacional para el Conocimiento y Uso de la Biodiversidad, México, D.F.

Xiao X., Hagen S., Zhang Q., Keller M. and Moore III B. 2006. Detecting leaf phenology of seasonally moist tropical forests in South America with multi-temporal MODIS images. Remote Sensing of Environment 103:465-473.

Yost A.C., Petersen S.L., Gregg M. and Miller R. 2008. Predictive modeling and mapping sage grouse (Centrocercus urophasian$u s$ ) nesting habitat using Maximum Entropy and a long-term dataset from Southern Oregon. Ecological Informatics 3:375-386.

Received: July 6, 2011

Accepted: February 8, 2012 